\title{
Influence of pinoxaden in mixtures with retardants on growth and yield of winter wheat
}

\author{
Wpływ pinoksadenu w mieszaninach z retardantami \\ na rozwój i plonowanie pszenicy ozimej
}

\author{
Wojciech Miziniak
}

\begin{abstract}
Summary
The field experiments on winter wheat cultivar Alcazar were conducted in 2011 and 2013. The applications of tested products were done at the stage $\mathrm{BBCH} 24$ of winter wheat (only herbicide) and pinoxaden with different growth regulators at the stage $\mathrm{BBCH}$ 31. Despite of the application method of pinoxaden (herbicide only or in mixture) high control effectiveness of Apera spica-venti was obtained in both years of the investigations. Better reduction of winter wheat height was achieved after using pinoxaden with growth regulators than when growth regulators were used alone. Depending on the investigation year the reduction of winter wheat culm was observed in the range from 12.9 to $16.1 \%$ for trinexapak ethyl (Modus 250 EC); 20.0 do 21.2\% for chlorequat chloride (Antywylegacz Płynny $725 \mathrm{SL}$ ); 7.5 do $12.2 \%$ for prohexadione-Ca (Regalis $10 \mathrm{WG).} \mathrm{Pinoxaden} \mathrm{applied} \mathrm{at} \mathrm{the} \mathrm{winter} \mathrm{wheat} \mathrm{growth} \mathrm{stage}$ $\mathrm{BBCH} 31$ reduced winter wheat height at the range from 2.2 to $6.2 \%$, too. Application of herbicide with CCC mixture or with prohexadione calcium resulted in a slight decrease in the weight of thousand seeds as compared to a separate application. In contrast, different correlations were found on the plots where mixtures of pinoxaden with trinexapac acetate were used. No significant differences in the yield of winter wheat among tested treatments were found.
\end{abstract}

Key words: winter wheat; pinoxaden; prohexadione-Ca; chloromequat chloride; trinexapak ethyl; yield grain

\begin{abstract}
Streszczenie
Doświadczenia polowe prowadzono w pszenicy ozimej odmiany Alcazar w latach 2011 i 2013. Aplikację badanych preparatów wykonano w fazie BBCH 24 pszenicy ozimej - sam herbicyd oraz w fazie BBCH 31 - mieszanina pinoksadenu z retardantami wzrostu. Niezależnie od sposobu aplikacji pinoksadenu w obydwu latach badań, uzyskano wysoką efektywność zwalczania miotły zbożowej. Łączne stosowanie pinoksadenu z retardantami wzrostu redukowało w większym stopniu wysokość pszenicy ozimej niż oddzielna aplikacja retardantów. W zależności od roku badań skrócenie źdźbeł pszenicy zawierało się w przedziale od 12,9 do 16,1 dla trineksapaku etylu (Modus 250 EC); od 20,0 do 21,2\% dla chlorku chloromekwatu (Antywylegacz Płynny 725 SL); od 7,5 do 12,2\% proheksadion wapnia (Regalis 10 WG). Pinoksaden stosowany w fazie BBCH 31 ograniczał także wysokość pszenicy ozimej w przedziale od 2,2 do 6,2\%. Mieszaniny pinoksadenu z chlorkiem chloromekwatu lub proheksadionem wapnia wpłynęły na nieznaczne obniżenie masy tysiąca nasion w porównaniu do oddzielnej aplikacji. Odmienne relacje stwierdzono w obiektach, w których zastosowano pinoksaden łącznie $z$ trineksapakiem etylu. W obydwu latach badań nie stwierdzono istotnych różnic w plonowaniu pszenicy ozimej pomiędzy badanymi wariantami.
\end{abstract}

Słowa kluczowe: pszenica ozima; pinoksaden; proheksadion wapnia; chlorek chloromekwatu; trineksapak etylu; plon ziarna 


\section{Wstęp / Introduction}

Intensyfikacja technologii uprawy roślin oraz wzrastające koszty produkcji przyczyniły się do poszukiwania bardziej oszczędnych rozwiązań mających na celu zagwarantowanie stabilnego plonowania zbóż. W związku z powyższym zaistniała potrzeba wdrożenia nowych rozwiązań w ochronie roślin, charakteryzujących się wysoką skutecznością, bezpieczeństwem dla środowiska oraz opłacalnością produkcji (Głazek i Mrówczyński 1999). Przykładem takich metod jest łączne stosowanie środków ochrony roślin, które redukuje koszty poniesione na ich aplikację, ogranicza niszczenie struktury gleby oraz usprawnia organizację pracy w gospodarstwie rolnym. Dodatkową korzyścią łącznego stosowania środków ochrony roślin jest możliwość wystąpienia efektu synergistycznego, co w konsekwencji prowadzi do polepszenia efektywności ich działania. W okresie wegetacji zbóż uzyskanie wysokich i dobrej jakości plonów uzależnione jest między innymi od eliminacji zachwaszczenia oraz zabezpieczenia upraw przed wyleganiem. Występujące w łanie chwasty, zwłaszcza miotła zbożowa (Apera spicaventi), silnie konkurują $\mathrm{z}$ rośliną uprawną o podstawowe składniki niezbędne dla wzrostu i rozwoju oraz przyczyniają się do wzrostu porażenia zbóż przez choroby grzybowe. Ważnym czynnikiem stabilizującym plony jest też ograniczenie wylegania roślin, które prowadzi do obniżenia plonowania, wzrostu kosztów związanych ze zbiorem, wydłużenia czasu koniecznego do jego przeprowadzenia oraz obniżenia jakości ziarna (Sterry i wsp. 1980; Kelbert i wsp. 2004; Tripathi i wsp. 2004). W celu zmniejszenia ryzyka wylegania, w intensywnej uprawie zbóż powszechnie stosowane są egzogenne związki ograniczające wzrost i rozwój roślin - retardanty wzrostu.

Istotnym problemem stosowania herbicydów i retardantów wzrostu w łącznym zabiegu jest dobranie odpowiedniego terminu ich aplikacji. Wiąże się to przede wszystkim z wczesnym terminem aplikacji herbicydów determinowanym fazą rozwojową chwastów oraz późniejszym stosowaniem retardantów wzrostu wynikającym $\mathrm{z}$ ich mechanizmu działania.

Celem badań było określenie wpływu łącznego stosowania pinoksadenu z retardantami wzrostu na skuteczność działania herbicydu oraz wybranych retardantów wzrostu w uprawie pszenicy ozimej.

\section{Materiały i metody / Materials and methods}

Doświadczenia polowe przeprowadzono w latach 2011 i 2013, w pszenicy ozimej odmiany Alcazar, w układzie statystycznym losowanych bloków w czterech powtórzeniach. Wielkość poletek wynosiła $12 \mathrm{~m}^{2}$. Obiektami badań były: herbicyd Axial 100 EC - (pinoksaden) stosowany $\mathrm{z}$ adiuwantem Adigor $440 \mathrm{EC} w$ dawkach odpowiednio 0,45 1/ha + 1,35 1/ha, Antywylegacz Płynny 725 SL (chlorek chloromekwatu - CCC) w dawce 2,0 1/ha, Moddus 250 EC (trineksapak etylu) - 0,4 1/ha oraz Regalis $10 \mathrm{WG}$ - (proheksadion wapnia) w dawce $0,5 \mathrm{~kg} / \mathrm{ha}$. Preparaty stosowano oddzielnie oraz $\mathrm{w}$ postaci mieszanin herbicydu $\mathrm{z}$ retardantem, przygotowanych $\mathrm{w}$ zbiorniku opryskiwacza. Zabiegi wykonywano w fazie $\mathrm{BBCH} 24$ (sam herbicyd) oraz w fazie BBCH 31 (sam retardant oraz mieszaniny herbicydu $\mathrm{z}$ regulatorami wzrostu). Zabiegi przeprowadzono przy użyciu opryskiwacza poletkowego „Victoria" wyposażonego w rozpylacze TEEJET 11002 VP, zużywając 2001 cieczy użytkowej w przeliczeniu na ha, $\mathrm{z}$ ciśnieniem roboczym $0,25 \mathrm{MPa}$.

Efektywność zniszczenia miotły zbożowej określono po wykłoszeniu zbóż za pomocą metody ramkowej. Pomiar wysokości roślin dokonano w fazie dojrzałości woskowej ziarniaków (BBCH 83), mierząc po 25 losowo wybranych roślin z każdego poletka. Określano długość źdźbła od powierzchni gleby do podstawy kłosa. W okresie wegetacji roślin przeprowadzano systematyczne, wizualne oceny wrażliwości pszenicy ozimej na aplikowane preparaty. Zakres występowania oraz natężenie zewnętrznych objawów uszkodzeń pszenicy określano w procentach $\mathrm{w}$ porównaniu do stanu roślin na poletkach kontrolnych $(0 \%$ - brak objawów fitotoksyczności, $100 \%$ całkowite zniszczenie roślin). W trakcie wegetacji roślin zastosowano nawożenie mineralne na poziomie $150 \mathrm{~kg} \mathrm{~N}$, $40 \mathrm{~kg} \mathrm{P} \mathrm{O}_{5}, 60 \mathrm{~kg} \mathrm{~K}$ O/ha oraz standardową ochronę przeciw chorobom i szkodnikom. Próby roślin do określenia struktury plonu pobrano $\mathrm{z}$ powierzchni $1 \mathrm{~m}^{2}$.

Analizie statystycznej poddano dane dotyczące obsady, wysokości roślin, liczby ziaren w kłosie, plonów ziarna oraz masy tysiąca ziaren. Wyniki testu Fishera oceniano na poziomie istotności $1 \mathrm{i} 5 \%$. Po stwierdzeniu istotnych różnic dokonano szczegółowego porównania średnich za pomocą testu t-Studenta, wyznaczając najmniejszą istotną różnicę na poziomie istotności $5 \%$.

\section{Wyniki i dyskusja / Results and discussion}

Efektywność działania środków ochrony roślin uzależniona jest w znacznym stopniu od warunków atmosferycznych. Według doniesień zawartych w pracach Toboły i Muśnickiego (1998) oraz Łęgowiak i Wysmułek (2000) temperatura powietrza może wpłynąć na obniżenie skuteczności działania retardantów wzrostu. W poszczególnych latach badań, w okresie stosowania środków zarejestrowano zróżnicowane średnie dobowe temperatury powietrza (tab. 1). W okresie 14 dni po zastosowaniu regulatorów wzrostu (2011 rok) zanotowano niższe wartości średniej dobowej temperatury powietrza niż w analogicznym przedziale czasowym 2013 roku, które wyniosły odpowiednio 11,5 i $16,8^{\circ} \mathrm{C}$. Należy podkreślić, że na przełomie kwietnia i maja 2011 roku, czyli w pierwszym tygodniu po zastosowaniu preparatów zarejestrowano wystąpienie przygruntowych przymrozków. Dla porównania w roku 2013 w okresie dwóch tygodni po aplikacji preparatów temperatury minimalne oscylowały w zakresie od 5,0 do $16,0^{\circ} \mathrm{C}$.

Analizując biologiczną efektywność pinoksadenu stosowanego łącznie z CCC można stwierdzić, że zaobserwowano tendencje do wzrostu efektywności zwalczania A. spica-venti $\mathrm{w} 2011$ roku, w porównaniu do oddzielnego stosowania środków. Odwrotne relacje odnotowano 
Tabela 1. Temperatura powietrza w okresie 14 dni po aplikacji preparatów

Table 1. Air temperature during14 days after application of growth regulators

\begin{tabular}{|c|c|c|c|c|c|c|}
\hline \multirow{4}{*}{$\begin{array}{l}\text { Dni } \\
\text { Days }\end{array}$} & \multicolumn{6}{|c|}{ Rok badań - Year of investigation } \\
\hline & \multicolumn{3}{|c|}{2011} & \multicolumn{3}{|c|}{2013} \\
\hline & \multicolumn{3}{|c|}{$\begin{array}{l}\text { temperatura powietrza - air temperature } \\
{\left[{ }^{\circ} \mathrm{C}\right]}\end{array}$} & \multicolumn{3}{|c|}{$\begin{array}{l}\text { temperatura powietrza - air temperature } \\
{\left[{ }^{\circ} \mathrm{C}\right]}\end{array}$} \\
\hline & $\begin{array}{c}\text { maksymalna } \\
\text { maximum }\end{array}$ & $\begin{array}{l}\text { minimalna } \\
\text { minimum }\end{array}$ & $\begin{array}{c}\text { średnia dobowa } \\
\text { avarage daily }\end{array}$ & $\begin{array}{c}\text { maksymalna } \\
\text { maximum }\end{array}$ & $\begin{array}{l}\text { minimalna } \\
\text { minimum }\end{array}$ & $\begin{array}{l}\text { średnia dobowa } \\
\text { avarage daily }\end{array}$ \\
\hline 1 & 18,0 & 5,0 & 12,5 & 28,0 & 15,0 & 21,3 \\
\hline 2 & 16,2 & 4,8 & 10,5 & 25,0 & 15,0 & 17,4 \\
\hline 3 & 15,5 & 4,0 & 8,9 & 22,0 & 12,0 & 14,3 \\
\hline 4 & 11,1 & $-1,2$ & 4,8 & 15,0 & 9,5 & 11,4 \\
\hline 5 & 11,2 & $-3,0$ & 3,2 & 16,5 & 10,0 & 13,1 \\
\hline 6 & 11,5 & $-0,4$ & 5,6 & 19,0 & 5,0 & 12,6 \\
\hline 7 & 17,5 & 0,5 & 10,2 & 22,2 & 7,0 & 16,0 \\
\hline 8 & 17,6 & 1,5 & 10,0 & 25,5 & 9,0 & 16,9 \\
\hline 9 & 19,6 & 5,5 & 12,4 & 27,0 & 12,0 & 19,8 \\
\hline 10 & 22,5 & 4,5 & 14,8 & 26,5 & 15,0 & 20,8 \\
\hline 11 & 26,0 & 9,5 & 18,0 & 25,0 & 10,0 & 18,5 \\
\hline 12 & 25,0 & 8,7 & 18,1 & 22,0 & 12,0 & 17,3 \\
\hline 13 & 25,0 & 11,5 & 19,5 & 27,5 & 16,0 & 20,9 \\
\hline 14 & 22,5 & 10,5 & 14,8 & 21,0 & 9,0 & 14,8 \\
\hline $\begin{array}{l}\text { Średnia } \\
\text { Avarage }\end{array}$ & - & - & 11,5 & - & - & 16,8 \\
\hline
\end{tabular}

Tabela 2. Wpływ łącznego stosowania pinoksadenu z retardantami na skuteczność chwastobójczą i wysokość roślin pszenicy w latach 2011 i 2013

Table 2. Influence of combined application of pinoxaden with growth regulators on weed control and height of winter wheat plants in years 2011 and 2013

\begin{tabular}{|c|c|c|c|c|c|c|c|c|c|c|c|}
\hline \multirow{2}{*}{$\begin{array}{l}\text { Lp. } \\
\text { No. }\end{array}$} & \multirow{2}{*}{$\begin{array}{l}\text { Obiekt } \\
\text { Treatment }\end{array}$} & \multirow{2}{*}{$\begin{array}{l}\text { Dawka } \\
\text { Dose } \\
{[1,} \\
\mathrm{kg} / \mathrm{ha}]\end{array}$} & \multirow{2}{*}{$\begin{array}{c}\text { Termin } \\
\text { aplikacji } \\
\text { Time of } \\
\text { applicatio } \\
n\end{array}$} & \multicolumn{2}{|c|}{$\begin{array}{c}\text { Efektywność } \\
\text { zniszczenia } \\
\text { Control } \\
\text { of APESV } \\
{[\%]}\end{array}$} & \multicolumn{2}{|c|}{$\begin{array}{c}\text { Fitotoksyczność } \\
\text { Phytotoxicity } \\
{[\%]}\end{array}$} & \multicolumn{4}{|c|}{$\begin{array}{l}\text { Wysokość roślin } \\
\text { Stem height } \\
{[\mathrm{cm}]}\end{array}$} \\
\hline & & & & 2011 & 2013 & 2011 & 2013 & 2011 & $\begin{array}{c}\text { redukcja } \\
\text { wyso- } \\
\text { kości } \\
\text { height } \\
\text { reduction } \\
\text { [\%] }\end{array}$ & 2013 & $\begin{array}{c}\text { redukcja } \\
\text { wyso- } \\
\text { kości } \\
\text { height } \\
\text { reduction } \\
\text { [\%] } \\
\end{array}$ \\
\hline 1 & 2 & 3 & 4 & 5 & 6 & 7 & 8 & 9 & 10 & 11 & 12 \\
\hline 1 & Kontrola - Untreated & - & - & $\begin{array}{c}69,7 \\
\mathrm{szt} . / \mathrm{m}^{2} \\
\mathrm{pcs} / \mathrm{m}^{2}\end{array}$ & $\begin{array}{c}32,3 \\
\mathrm{szt} . / \mathrm{m}^{2} \\
\mathrm{pcs} / \mathrm{m}^{2}\end{array}$ & 0 & 0 & 58,9 a & - & $67,8 \mathrm{a}$ & - \\
\hline 2 & $\begin{array}{l}\text { Axial } 100 \text { EC + Adigor } \\
440 \text { EC/Moddus } 250 \text { EC }\end{array}$ & $\begin{array}{c}0,45+ \\
1,35 / 0,4 \\
\end{array}$ & $\mathrm{~A} / \mathrm{B}$ & $98,0 \mathrm{a}$ & $100 \mathrm{a}$ & 0 & 0 & $52,2 \mathrm{c}$ & $-11,4$ & $60,2 \mathrm{bcd}$ & $-11,2$ \\
\hline 3 & $\begin{array}{l}\text { Axial } 100 \text { EC + Adigor } \\
440 \mathrm{EC}+\text { Moddus } 250 \mathrm{EC}\end{array}$ & $\begin{array}{c}0,45+ \\
1,35+ \\
0,4 \\
\end{array}$ & B & 94,7 a & $100 \mathrm{a}$ & 0 & 0 & $51,3 \mathrm{~cd}$ & $-12,9$ & 56,9 def & $-16,1$ \\
\hline 4 & $\begin{array}{l}\text { Axial } 100 \text { EC + Adigor } \\
440 \text { EC/Antywylegacz } \\
\text { Płynny } 725 \text { SL }\end{array}$ & $\begin{array}{c}0,45+ \\
1,35 / 2,0\end{array}$ & $\mathrm{~A} / \mathrm{B}$ & 95,3 a & $100 \mathrm{a}$ & 0 & 0 & $47,1 \mathrm{de}$ & $-20,0$ & 56,2 ef & $-17,1$ \\
\hline 5 & $\begin{array}{l}\text { Axial } 100 \text { EC + Adigor } \\
440 \text { EC + Antywylegacz } \\
\text { Płynny } 725 \text { SL }\end{array}$ & $\begin{array}{c}0,45+ \\
1,35+ \\
2,0 \\
\end{array}$ & $\mathrm{~B}$ & 99,6 a & $100 \mathrm{a}$ & 0 & 0 & $46,4 \mathrm{e}$ & $-21,2$ & $54,2 \mathrm{f}$ & $-20,0$ \\
\hline 6 & $\begin{array}{l}\text { Axial } 100 \text { EC + Adigor } \\
440 \text { EC/Regalis } 10 \mathrm{WG}\end{array}$ & $\begin{array}{c}0,45+ \\
1,35 / 0,5 \\
\end{array}$ & $\mathrm{~A} / \mathrm{B}$ & $98,5 \mathrm{a}$ & $100 \mathrm{a}$ & 0 & 0 & $53,4 \mathrm{bc}$ & $-9,3$ & $61,7 \mathrm{bc}$ & $-9,0$ \\
\hline
\end{tabular}




\begin{tabular}{c|l|c|c|c|c|c|c|c|c|c|c}
\hline 1 & \multicolumn{1}{|c|}{2} & 3 & 4 & 5 & 6 & 7 & 8 & 9 & 10 & 11 & 12 \\
\hline 7 & $\begin{array}{l}\text { Axial 100 EC + Adigor } \\
440 \text { EC + Regalis } \\
10 \text { WG }\end{array}$ & $\begin{array}{c}0,45+ \\
1,35+ \\
0,5\end{array}$ & B & $99,1 \mathrm{a}$ & $100 \mathrm{a}$ & 0 & 0 & $54,5 \mathrm{abc}$ & $-7,5$ & $59,5 \mathrm{cde}$ & $-12,2$ \\
\hline 8 & $\begin{array}{l}\text { Axial 100 EC + Adigor } \\
440 \text { EC }\end{array}$ & $\begin{array}{c}0,45+ \\
1,35\end{array}$ & B & $98,7 \mathrm{a}$ & $100 \mathrm{a}$ & 0 & 0 & $57,6 \mathrm{ab}$ & $-2,2$ & $63,6 \mathrm{~b}$ & $-6,2$ \\
\hline
\end{tabular}

A - termin aplikacji BBCH 24 - pszenicy ozimej - date of application BBCH 24 of winter wheat

$\mathrm{B}$ - termin aplikacji BBCH 31- pszenicy ozimej - date of application BBCH 31 of winter wheat

$\mathrm{a}, \mathrm{b}, \mathrm{c}, \mathrm{d}$ - grupy jednorodne - homogeneous groups

r.n. - różnica nieistotna - not significant difference

APESV - Apera spica-venti

w przypadku oceny mieszanin herbicydu z trineksapakiem etylu, natomiast sposób stosowania pinoksadenu $\mathrm{z}$ proheksadionem wapnia nie miał wpływu na skuteczność zwalczania tego chwastu (tab. 2). W drugim roku badań, niezależnie od sposobu aplikacji pinoksadenu (sam herbicyd lub mieszanina $\mathrm{z}$ retardantami wzrostu) uzyskano $100 \%$ zniszczenie miotły zbożowej. Pomimo zaistniałych różnic w 2011 roku, uzyskane średnie w poszczególnych latach badań pod względem statystycznym nie różniły się istotnie. Według niektórych autorów łączne stosowanie herbicydów z retardantami przyczynia się do polepszenia efektywności chwastobójczej stosowanych mieszanin (Kieloch i wsp. 2010; Miziniak 2011; Marczewska-Kolasa i Kieloch 2012). Odmienne rezultaty osiągnął Krawczyk (2006) badając możliwości stosowania florasulamu z regulatorami wzrostu. Autor uzyskał wzrost efektywności zwalczania chwastów jedynie w przypadku dodania adiuwanta do cieczy opryskowej zawierającej florasulam i regulatory wzrostu (trineksapak etylu i CCC).

Na podstawie wykonanych badań można stwierdzić, że mieszaniny preparatów w większym stopniu ograniczyły wysokość pszenicy ozimej niż oddzielna aplikacja środków. Największą redukcję wysokości źdźbeł pszenicy uzyskano po zastosowaniu pinoksadenu łącznie z trinieksapakiem etylu lub z CCC. W zależności od roku badań skrócenie źdźbeł wynosiło od 12,9 do $16,1 \%$ dla trineksapaku etylu oraz od 21,2 do $20,0 \%$ dla CCC. W przypadku oceny łącznego stosowania pinoksadenu $\mathrm{z}$ proheksadionem wapnia w obydwu latach badań odnotowano zróżnicowane działanie. W 2011 roku mieszaniny preparatów ograniczyły wysokość zbóż w mniejszym zakresie niż oddzielne stosowanie preparatów, natomiast w 2013 roku wykazywały lepszą efektywność retardacyjną. W 2013 roku efektywność działania mieszanin pinoksadenu z trineksapakiem etylu lub z proheksadionem wapnia była większa niż w pierwszym roku badań. Na podstawie przeprowadzonych analiz statystycznych stwierdzono istotne ograniczenie wysokości pszenicy ozimej jedynie dla roślin z obiektu kontrolnego w porównaniu do tych traktowanych łącznie lub oddzielnie badanymi retardantami wzrostu (tab. 2). Na lepsze działanie retardantów stosowanych łącznie z herbicydami zwracają uwagę także inni autorzy (Pietryga i Mączyńska 1999; Pietryga i Drzewiecki 2000; Krawczyk 2006; Miziniak 2011).

W dostępnej literaturze można znaleźć pogląd o retardacyjnych właściwościach niektórych substancji czynnych herbicydów. Według Miziniaka (2011) fenoksaprop-P- etylowy powodował skrócenie źdźbeł o 5,5\% w porów naniu do obiektu kontrolnego. W prezentowanych badaniach uzyskano podobne relacje. W zależności od roku badań pinoksaden ograniczył wysokość źdźbeł pszenicy ozimej w zakresie od 2,2\% w 2011 roku do 6,2\% w 2013 roku w porównaniu do nietraktowanego obiektu kontrolnego.

W doświadczeniu oceniano również wpływ sposobu stosowania preparatów na poszczególne elementy struktury plonu (tab. 3). Zastosowanie pinoksadenu łącznie $\mathrm{z}$ proheksadionem wapnia zwiększało obsadę źdźbeł w porównaniu do zastosowania tych preparatów oddzielnie. Wraz ze wzrostem obsady malała średnia ilość ziarniaków w kłosie. W pozostałych wariantach badań odnotowano duże zróżnicowanie omawianych cech w poszczególnych latach badań. Pszenica ozima opryskiwana retardantami niezależnie od sposobu ich stosowania, odznaczała się niższą masą tysiąca ziaren niż ziarno zebrane $\mathrm{z}$ poletek traktowanych samym herbicydem. Łączne stosowanie pinoksadenu z CCC lub proheksadionem wapnia wpływało na obniżenia masy tysiąca ziarniaków pszenicy ozimej w porównaniu do obiektów, w których stosowano preparaty oddzielnie. Odwrotne relacje uzyskano w przypadku oceny łącznego stosowania pinoksadenu z trineksapakiem etylu.

W obiektach, w których zastosowano mieszaniny badanych preparatów obserwowano wzrost plonowania pszenicy ozimej w porównaniu do plonów uzyskanych z obiektów bez zabiegu. Powyższą zależność stwierdzono w przypadku zastosowania mieszanin pinoksadenu $\mathrm{z}$ trineksapakiem etylu. Analizując wpływ mieszanin opartych na bazie pinoksadenu i CCC stwierdzono wyrównane plonowanie pszenicy ozimej w obydwu latach badań niezależnie od sposobu zastosowania preparatów. Największe różnice w obydwu latach badań odnotowano w obiektach, w których stosowano pinoksaden łącznie $\mathrm{z}$ proheksadionem wapnia. W roku 2011 wystąpił istotny wzrost masy ziarna, natomiast w 2013 roku obserwowano spadek plonowania. Plony ziarna z obiektów, w których aplikowano retardanty, niezależnie od sposobu ich aplikacji były w większości przypadków wyższe od masy ziarna zebranej poletek, na których zastosowano sam herbicyd.

Według licznych autorów retardanty wzrostu przyczyniają się do polepszenia plonowania zbóż. Biorąc pod uwagę wpływ zastosowanych preparatów na poszczególne komponenty struktury plonu, w większości prac naukowych można znaleźć pogląd o korzystnym wpływie tych preparatów na obsadę źdźbeł kłosonośnych na jednostce powierzchni oraz liczbę ziaren w kłosie (Starczewski i wsp. 
Tabela 3. Wpływ łącznego stosowania pinoksadenu z retardantami wzrostu na plon ziarna i wybrane parametry plonu w latach 2011 i 2013

Table 3. Influence of combined application of pinoxaden with growth regulators on grain yield and some yield parameters in years 2011 and 2013

\begin{tabular}{|c|c|c|c|c|c|c|c|c|c|c|c|}
\hline \multirow[t]{2}{*}{$\begin{array}{l}\text { Lp. } \\
\text { No. }\end{array}$} & \multirow[t]{2}{*}{$\begin{array}{c}\text { Obiekt } \\
\text { Treatment }\end{array}$} & \multirow[t]{2}{*}{$\begin{array}{l}\text { Dawka } \\
\text { Dose } \\
{[1,} \\
\mathrm{kg} / \mathrm{ha}]\end{array}$} & \multirow[t]{2}{*}{$\begin{array}{l}\text { Termin } \\
\text { aplikacji } \\
\text { Time of } \\
\text { application }\end{array}$} & \multicolumn{2}{|c|}{$\begin{array}{l}\text { Obsada źdźbeł } \\
{[\text { szt./m²] }} \\
\text { Stem density } \\
{\left[\mathrm{pcs} / \mathrm{m}^{2}\right]}\end{array}$} & \multicolumn{2}{|c|}{$\begin{array}{c}\text { MTZ } \\
1000 \text { grain weight } \\
{[\mathrm{g}]}\end{array}$} & \multicolumn{2}{|c|}{$\begin{array}{c}\text { Liczba } \\
\text { ziaren w kłosie } \\
\text { [szt./kłos] } \\
\text { No. of grains } \\
\text { per one earn } \\
\text { [pcs/ear] }\end{array}$} & \multicolumn{2}{|c|}{$\begin{array}{l}\text { Plon ziarna } \\
\text { Grain yield } \\
\text { [t/ha }]\end{array}$} \\
\hline & & & & 2011 & 2013 & 2011 & 2013 & 2011 & 2013 & 2011 & 2013 \\
\hline 1 & $\begin{array}{l}\text { Kontrola } \\
\text { Untreated }\end{array}$ & - & - & $500,7 \mathrm{ab}$ & 568,0 a & $36,94 \mathrm{bc}$ & $35,82 \mathrm{~b}$ & $33,3 \mathrm{~d}$ & $38,9 \mathrm{a}$ & $6,14 \mathrm{c}$ & $7,91 \mathrm{a}$ \\
\hline 2 & $\begin{array}{l}\text { Axial } 100 \mathrm{EC}+ \\
\text { Adigor } 440 \mathrm{EC} / \\
\text { Moddus } 250 \mathrm{EC}\end{array}$ & $\begin{array}{c}0,45+ \\
1,35 / \\
0,4\end{array}$ & $\mathrm{~A} / \mathrm{B}$ & $516,0 \mathrm{ab}$ & $508,0 \mathrm{a}$ & $36,88 \mathrm{bc}$ & $34,90 \mathrm{~b}$ & $36,3 \mathrm{~cd}$ & $41,2 \mathrm{a}$ & $6,90 \mathrm{c}$ & $7,31 \mathrm{a}$ \\
\hline 3 & $\begin{array}{l}\text { Axial } 100 \mathrm{EC}+ \\
\text { Adigor } 440 \mathrm{EC}+ \\
\text { Moddus } 250 \mathrm{EC}\end{array}$ & $\begin{array}{c}0,45+ \\
1,35+ \\
0,4 \\
\end{array}$ & B & $497,3 \mathrm{abc}$ & $576,0 \mathrm{a}$ & $38,01 \mathrm{abc}$ & $36,23 \mathrm{ab}$ & $38,0 \mathrm{bc}$ & $38,8 \mathrm{a}$ & $7,17 \mathrm{bc}$ & $8,02 \mathrm{a}$ \\
\hline 4 & $\begin{array}{l}\text { Axial } 100 \mathrm{EC}+ \\
\text { Adigor } 440 \mathrm{EC} / \\
\text { Antywylegacz } \\
\text { Płynny } 725 \mathrm{SL}\end{array}$ & $\begin{array}{c}0,45+ \\
1,35 / \\
2,0\end{array}$ & $\mathrm{~A} / \mathrm{B}$ & $396,7 \mathrm{c}$ & 553,7 a & $37,79 \mathrm{abc}$ & $34,55 \mathrm{~b}$ & $45,5 \mathrm{a}$ & $41,2 \mathrm{a}$ & $6,74 \mathrm{c}$ & $8,56 \mathrm{a}$ \\
\hline 5 & $\begin{array}{l}\text { Axial } 100 \mathrm{EC}+ \\
\text { Adigor } 440 \mathrm{EC}+ \\
\text { Antywylegacz } \\
\text { Płynny } 725 \mathrm{SL}\end{array}$ & $\begin{array}{c}0,45+ \\
1,35+ \\
2,0\end{array}$ & B & $498,7 \mathrm{abc}$ & $584,0 \mathrm{a}$ & $36,06 \mathrm{c}$ & $34,40 \mathrm{~b}$ & $38,7 \mathrm{bc}$ & $41,9 \mathrm{a}$ & $6,95 \mathrm{c}$ & $8,40 \mathrm{a}$ \\
\hline 6 & $\begin{array}{l}\text { Axial } 100 \mathrm{EC}+ \\
\text { Adigor } 440 \mathrm{EC} / \\
\text { Regalis } 10 \mathrm{WG} \\
\end{array}$ & $\begin{array}{c}0,45+ \\
1,35 / \\
0,5 \\
\end{array}$ & $\mathrm{~A} / \mathrm{B}$ & $428,7 \mathrm{bc}$ & $549,3 \mathrm{a}$ & $39,11 \mathrm{ab}$ & $36,55 \mathrm{ab}$ & $40,4 \mathrm{bc}$ & $41,6 \mathrm{a}$ & $6,74 \mathrm{c}$ & $8,32 \mathrm{a}$ \\
\hline 7 & $\begin{array}{l}\text { Axial } 100 \mathrm{EC}+ \\
\text { Adigor } 440 \mathrm{EC}+ \\
\text { Regalis } 10 \mathrm{WG}\end{array}$ & $\begin{array}{c}0,45+ \\
1,35+ \\
0,5\end{array}$ & B & $542,7 \mathrm{a}$ & $561,3 \mathrm{a}$ & $38,03 \mathrm{abc}$ & $34,55 \mathrm{~b}$ & $40,0 \mathrm{bc}$ & $37,2 \mathrm{a}$ & $8,23 \mathrm{ab}$ & $7,19 \mathrm{a}$ \\
\hline 8 & $\begin{array}{l}\text { Axial } 100 \mathrm{EC}+ \\
\text { Adigor } 440 \mathrm{EC}\end{array}$ & $\begin{array}{c}0,45+ \\
1,35\end{array}$ & B & $495,3 \mathrm{abc}$ & $565,3 \mathrm{a}$ & $40,26 \mathrm{a}$ & 38,19 a & $42,0 \mathrm{ab}$ & $39,6 \mathrm{a}$ & $8,33 \mathrm{a}$ & $8,56 \mathrm{a}$ \\
\hline NIR & $0,05)-\operatorname{LSD}(0.05)$ & - & - & 102,83 & r.n. & 2,572 & 2,338 & 4,46 & r.n. & 1,128 & r.n. \\
\hline
\end{tabular}

A - termin aplikacji BBCH 24 - pszenicy ozimej - date of application BBCH 24 of winter wheat B - termin aplikacji BBCH 31- pszenicy ozimej - date of application BBCH 31 of winter wheat a, b, c, d - grupy jednorodne - homogeneous groups

r.n. - różnica nieistotna - not significant difference

2002). Najwięcej rozbieżności dotyczy wpływu retardantów wzrostu na masę tysiąca ziaren (Giltrap i Garstang 1991; Woolley 1991; Starczewski i wsp. 2002).

W obydwu latach badań nie stwierdzono fitotoksycznego oddziaływania badanych mieszanin na pszenicę ozimą odmiany Alcazar. Również badania przeprowadzane przez Krawczyka (2006), Kieloch i wsp. (2010) oraz Miziniaka (2011) potwierdzają możliwości łącznego stosowania herbicydów $\mathrm{z}$ retardantami bez wystąpienia fitotoksycznego działania na pszenicę ozimą.

\section{Wnioski / Conclusions}

1. Sposób aplikacji pinoksadenu (samodzielnie lub mieszaninach $\mathrm{z}$ retardantami wzrostu) nie miały istotnego wpływu na efektywność zwalczania miotły zbożowej.
2. Mieszaniny pinoksadenu $\mathrm{z}$ retardantami wzrostu były w pełni selektywne dla pszenicy ozimej odmiany Alcazar.

3. W obydwu sezonach wegetacyjnych badane mieszaniny w większym stopniu ograniczały wysokość roślin pszenicy ozimej niż oddzielne stosowanie tych środków. W przypadku łącznego stosowania herbicydu $\mathrm{z}$ proheksadionem wapnia taki efekt uzyskano jedynie w 2013 roku.

4. W dwuletnich badaniach stwierdzono redukcję wysokości pszenicy ozimej po zastosowaniu pinoksadenu. W zależności od roku skrócenie źdźbeł pszenicy zawierało się w przedziale od 2,2 do $6,2 \%$ w porównaniu do obiektu kontrolnego.

5. Łączne stosowanie pinoksadenu $\mathrm{z}$ chlorkiem chloromekwatu lub proheksadionem wapnia wpłynęło na nieznaczne obniżenie masy tysiąca ziaren. 
6. Plony ziarna zebrane $\mathrm{z}$ poletek traktowanych mieszaninami pinoksadenu $\mathrm{z}$ retardantami były wyższe od uzyskanych z obiektów kontrolnych oraz tych, na których zastosowano badane preparaty oddzielnie.

\section{Literatura / References}

Giltrap N.J., Garstang J.R.1991. Effect of PGRS and nitrogen rate on grain yield and quality of Marinka winter barley. The BCPC Weeds 7C-10: 987-994.

Głazek M., Mrówczyński M. 1999. Łączne stosowanie agrochemikaliów w nowoczesnej technologii produkcji zbóż. Pam. Puł. 114: $119-126$.

Kelbert A.J., Spaner D., Briggs K.G., King J.R. 2004. The association of culm anatomy with lodging susceptibility in modern spring wheat genotypes. Euphytica 136: 211-221.

Kieloch R., Marczewska-Kolasa K., Domaradzki K. 2010. Wpływ sposobu i terminu aplikacji CCC i fluroksypyru na zniszczenie chwastów i plonowanie pszenicy ozimej. [The influence of metod and application time on weed control and wheat field]. Prog. Plant Prot./Post. Ochr. Roślin 50 (2): 803-806.

Krawczyk R. 2006. Badania nad efektywnością łącznego stosowania florasulamu z regulatorami wzrostu roślin w zwalczaniu chwastów w pszenicy ozimej. [Studies on effectivity on application of tank-mixture florasulam with growth regulators in the weed control in winter wheat]. Prog. Plant Prot./Post. Ochr. Roślin 46 (2): 200-204.

Łęgowiak Z., Wysmułek A. 2000. Stosowanie regulatorów wzrostu w zbożach. [Plant growth regulators in cereals]. Prog. Plant Prot./Post. Ochr. Roślin 40 (2): 932-934.

Marczewska-Kolasa K., Kieloch R. 2012. Ocena łącznego stosowania amidosulfuronu z CCC w zależności od fazy rozwojowej pszenicy ozimej. [Possibility of combined application of amidosulfuron with CCC depending on winter wheat growth stage]. Prog. Plant Prot./Post. Ochr. Roślin 52 (3): 567-571.

Miziniak W. 2011. Wpływ łącznego stosowania herbicydów: Puma Universal 069 EW i Attribut 70 WG z regulatorami wzrostu na właściwości fizyko-chemiczne cieczy opryskowych i skuteczność działania badanych mieszanin. [Influence of mix application of fenoxaprop-p-ethyl and propoxycarbazone sodium with growth regulators on physics-chemical properties of spray liquid and their effectiveness]. Prog. Plant Prot./Post. Ochr. Roślin 51 (2): 943-949.

Pietryga J., Mączyńska A. 1999. Łączne stosowanie herbicydu Chisel 75 WG z regulatorami wzrostu i adiuwantami w pszenicy ozimej. [The combined application of Chisel 75 WG with growth regulators and adjuvants in winter wheat protections]. Prog. Plant Prot./Post. Ochr. Roślin 39 (2): 714-717.

Pietryga J., Drzewiecki S. 2000. Integracja zabiegów chemicznych w pszenicy ozimej poprzez łączne zastosowanie herbicydu $\mathrm{z}$ regulatorem wzrostu, fungicydem i adiuwantami. [Integration of chemical control protection in winter wheat through joint application oh herbicide with growth regulators, fungicide and adjuvants]. Prog. Plant Prot./Post. Ochr. Roślin 40 (2): $667-671$.

Starczewski J., Bombik A., Dopka D. 2002. Plonowanie i struktura plonu pszenżyta ozimego w zależności od nawożenia azotem i wybranych retardantów. Folia Univ. Agric. Stetin. Agricultura 228 (91): 147-154.

Sterry J.R. 1980. Ethephon as a plant growth regulator on winter barley: results and present status in Europe. The BCPC - Weeds: 687-692.

Toboła P., Muśnicki Cz. 1998. Wpływ etefonu na wzrost, rozwój i plonowanie słonecznika oleistego. Materiały 35. Sesji Nauk. Inst. Ochr. Roślin, cz. 1: 338-341.

Tripathi S.C., Sayre K.D., Kaul J.N., Narang R.S. 2004. Lodging behavior and yield potential of spring wheat (Triticum aestrivum L.) effects of ethephon and genotypes. Field Crops Res. 87: 207-220.

Woolley E.W. 1991. Recent experience of timing of growth regulators on winter wheat. The BCPC - Weeds 7C-10: 981-986. 